\title{
Enriching academic vocabulary of the undergraduates in technological study stream in Sri Lanka: A comparative exploration of the effectiveness of Virtual Blended and
} Face-to-Face modes

\author{
${ }^{1}$ R. P. Dharmawardene, ${ }^{2}$ T. A. Weerasinghe, ${ }^{3}$ M.G.L. Ananda. \\ ${ }^{1}$ Faculty of Graduate Studies, University of Colombo. \\ ${ }^{2}$ UCSC, University of Colombo. \\ ${ }^{3}$ Faculty of Social Sciences and Humanities, University of Sri \\ Jayewardenepura.
}

\begin{abstract}
This mixed method case study explored and compared the effectiveness of the Virtual Blended Mode (VBM) and the fully F2F mode in improving academic vocabulary of the undergraduates learning English as a Second Language (ESL) in the F2F mode at the Faculty of Technology in the University of Colombo (UOC). The theoretical alignment was Vygotsky's (1978) Sociocultural Theory and Anderson's (1977) Schema Theory. The qualitative part of the study included questionnaire responses from 21 visiting lecturers of English, of the Department of English Language Teaching, UOC, on the most commonly used vocabulary strategy to enhance receptive and productive vocabulary of the undergraduates. The quantitative part of the study included a receptive vocabulary test and a productive vocabulary test with 36 test items. Semantic Mapping strategy (Graves, 2008) was used for vocabulary development activities. Two samples consisted of 96 participants with limited prior knowledge and 78 with higher level of prior knowledge in ESL purposefully were selected based on the grades obtained at their G.C.E. A/L Examination in 2016/2017. Both samples were further grouped as VBM and F2F randomly assigning participants. Two experimental (VBM) groups underwent the intervention with 120 academic vocabulary activities using the Learning Management System (LMS) created for this study while the two control groups practiced the same activities in their F2F classes. All participants used the semantic mapping strategy. The LMS was facilitated with the newest feature of the Web 2.0 technology, the BigBlueButton feature enabling the participants to work collaboratively in small groups online. Receptive and productive
\end{abstract}


vocabulary tests were administered to all participants. Rubric was used to assign scores for answers of the tests. Data analysis focused on the receptive and productive levels of improvement in academic vocabulary. The results showed a significant improvement in the receptive vocabulary development of the participants in the VBM groups in both samples who had the opportunity to practice in a better collaborative environment interacting with their peers 10 percent of the time in F2F mode and 90 percent of the time online compared to their counterparts who practiced 100 percent of the time in the F2F mode proving Vygotsky's (1978) Sociocultural Theory. However, the participants with limited prior knowledge in ESL performed less in productive test compared to their receptive test showing difficulty in using new words in new contexts proving the Schema Theory (Anderson, 1977) while the participants with higher knowledge performed well in the productive tests disregarding the mode of delivery being utilized. Thus, the study highlights the pedagogical implications for teaching academic English in the context of teaching ESL in Universities in Sri Lanka.

Keywords: Academic vocabulary, Collaborative learning, English as a second language, Face-to-Face learning, Virtual Blended Learning.

\section{Introduction}

When the Sri Lankan government first introduced the technological study stream to the G.C.E. Advanced Level examination in 2013 all the secondary schools in the country except Royal College and Visakha Vidyalaya in Colombo offered the subjects in the new stream to their students enabling them to master technology related subjects at their tertiary level. The technological study stream contains three subject categories; A, B and C. candidates can select Engineering Technology or Bio-system Technology from category A with Science for Technology as category B subject, and information communication technology, or any other subject from the category C subject group. Science for Technology (Category B) is a compulsory subject for both Engineering and Bio-system candidates. Once the students obtain a required Z-score to enter a technological faculty, they should follow the degree in the medium of English. ESL was made a compulsory subject for all the students in all Technology Faculties in order to facilitate better learning (UGC, 2014). 


\section{Enriching academic vocabulary of the undergraduates in technological study stream in Sri Lanka: A comparative exploration of the effectiveness of Virtual Blended and Face-to-Face modes}

The lack of English language competency among undergraduates in Sri Lanka has been a persistent issue even though they have been studying English as a second language (ESL) throughout their school career (Sareen, 2009). The semester exam results of the undergraduates learning ESL in the Faculty of Technology in the University of Colombo reveal that they find it challenging to perform well in the English medium as they lack required level of knowledge in academic vocabulary. Teaching academic vocabulary is currently being done in the traditional Face-to-Face (F2F) mode. This mixed method case study explored and compared the effectiveness of the Virtual Blended Mode (VBM) that used 90 percent of the learning time online and the fully F2F mode that used 100 percent of the learning time in the traditional mode with regard to improving their academic vocabulary.

The following three research questions guided this study.

1. To identify the most commonly used vocabulary teaching strategy by the lecturers of ESL at the faculty of Technology in the University of Colombo in teaching English academic vocabulary.

2. To examine how far the two modes of delivery, VBM and F2F can be effective in developing receptive and productive academic vocabulary of the participants with limited prior knowledge in ESL.

3. To examine how far the two modes of delivery, VBM and F2F can be effective in developing receptive and productive academic vocabulary of the participants with higher level of prior knowledge in ESL.

\section{Literature Review}

As the Oxford Advanced Dictionary (2018) defines, vocabulary is knowledge about words and their meanings. It is the body of words used in a particular language (Laufer, 2011). Words are the primary blocks of effective communication. Vocabulary is a crucial component for any second language learner since a limited vocabulary will be an obstacle to successful communication. However, word knowledge is not an all-or-nothing phenomenon. A person may be able to listen and understand a word but may not be able to use it in his or her speech and writing. This is referred to as the difference between receptive and productive vocabulary. 
The three main types of vocabulary are depicted in the Figure 1 below as Tiered vocabulary.

Figure 1: Common Core State Standards (CCSS)-2010

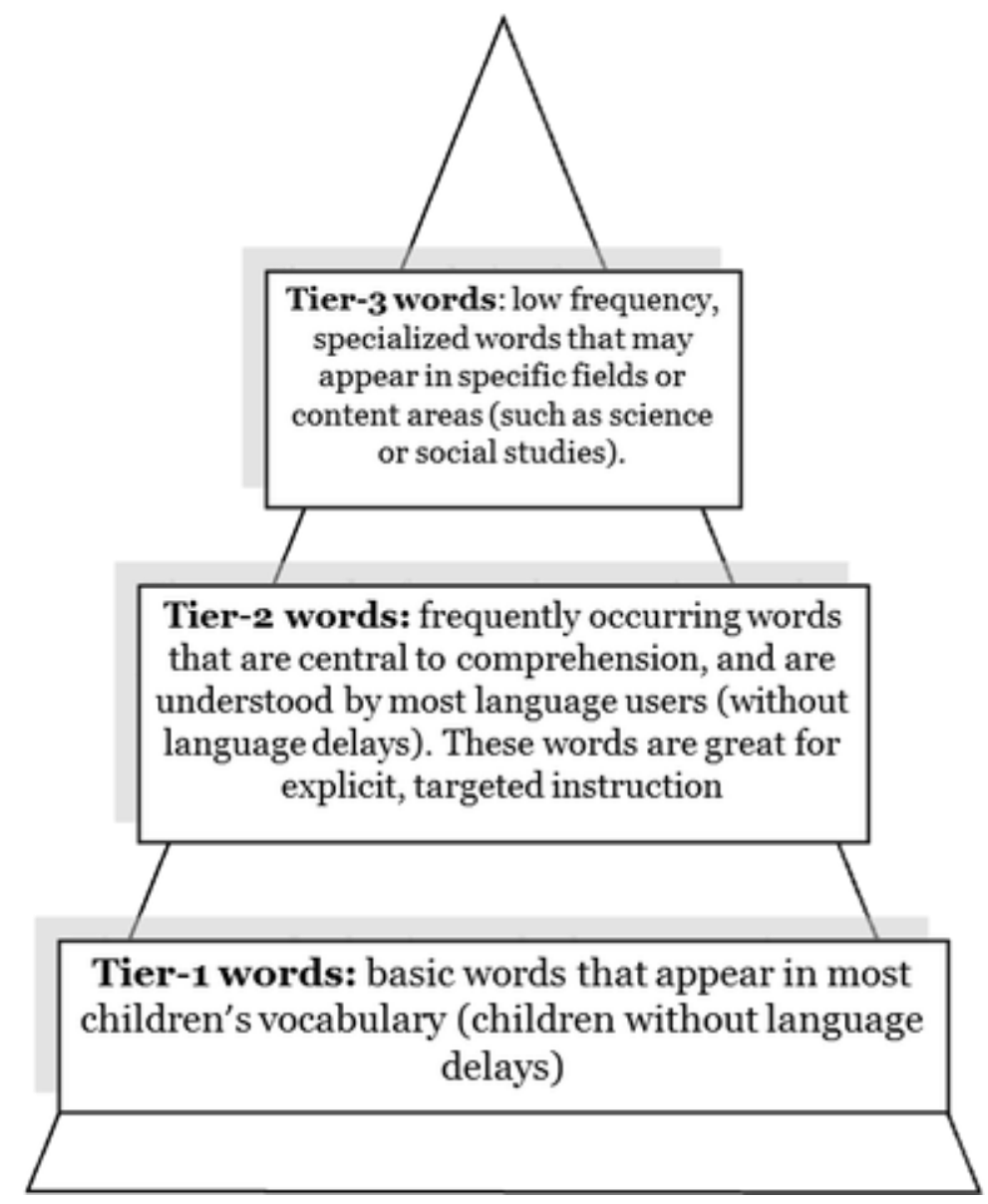

The Common Core State Standards (2010) label the words as Tier one, Tier two and Tier three. The top tier three words are the domain specific words which are taught by the content area teachers, but the tier two academic words are generally neglected. Tier one consists of the common words used daily which the learners can learn easily. Short et.al, (2010) have drawn a comparison of the domain specific (Tier three) words to bricks and general academic words (Tier two) to mortar. Both these tiers of words are vital to build a strong foundation of vocabulary. 


\section{Enriching academic vocabulary of the undergraduates in technological study stream in Sri Lanka: A comparative exploration of the effectiveness of Virtual Blended and Face-to-Face modes}

According to Coxhead and Nation (2001), vocabulary can be divided into four categories. This classification would include the General vocabulary or the High frequency vocabulary, Academic vocabulary, Technical vocabulary and Low frequency words.

Coxhead and Nation's (2001) classification of vocabulary is given below.

1- General Service List (GSL): This contains the high frequency words which belong to the General Service List (GSL) of Michael West (1953). These are the most widely used 2,000-word families in English, covering about 80 percent of most of the texts. A learner generally encounters these words most of the time daily. S/he may come across these words while reading a newspaper, novel, a textbook, an academic journal article, or while listening to the radio or a lecture or a television program (Nation and Waring, 1997). The GSL is divided into the first and second most frequent 1000 words.

2- Academic vocabulary: These are the words which belong to the Academic Word List (AWL) of Coxhead (2000). It consists of 570-word families comprising nearly ten percent of the words in academic texts of various disciplines. Xue and Nation (1984) compiled the University Word List (UWL), which is made of 836 items and covers about 8.5 percent of the words in academic texts (Nation and Waring, 1997).

3- Technical vocabulary: These words cover up to five percent of words in texts and are relevant to the different subject areas. Since technical vocabulary is central to students' specialized areas, general academic vocabulary serves as a supportive role and these words are "not likely to be glossed by the content teacher" (Eldridge, 2008, p.236). The technical words are also referred to as domain specific academic vocabulary. Many of these words occur too infrequently to allow incidental learning (Worthington and Nation, 1996) encouraging researchers and teachers to develop vocabulary lists of explicit teaching.

4- Low frequency vocabulary: These consist of words that are very narrow in range and low frequency. Such words occur very rarely in a text. i.e. once or twice in a long academic text. Low frequency vocabulary is for 
learners who "intend to use English for social purposes that do not require the reading of academic text or for reading novels and popular magazines" (Nation and Newton, 1997, p. 239). As these words are rarely found in academic texts, it is not worthwhile spending time on such words for the undergraduates at the tertiary level.

Academic vocabulary is the vocabulary critical to understanding the concepts of the content taught to the ESL learners (Nation, 2001). It enables learners to learn the word origins, multiple meaning of words, and acquire a thorough understanding of the abstract concepts which are related to the content area of their discipline. The need for academic vocabulary for ESL in the content area of study has been emphasized by many researchers in the area of vocabulary research. According to Stahl and Nagy (2006), academic vocabulary is one of the strongest indicators of how well students will learn subject area content. They have also pointed out that academic vocabulary is crucial to improve both reading comprehension and verbal IQ. According to Marzano and Pickering (2005), the more students understand academic vocabulary terms, the easier it is to understand information on a given topic.

"Academic vocabulary is the language that is used by teachers and students for the purpose of acquiring new knowledge and skills, which includes learning new information, describing abstract ideas and developing students' conceptual understanding" (Chamot and O'Malley, 2007 as cited in Herrel, 2004). Stahl (2006) found that a deeper understanding of academic vocabulary is needed to understand new concepts. According to Cummins (2002) as cited in Herrel (2004), individuals who can express themselves precisely with appropriate language are more likely to make a positive impression on their employers, colleagues and clients. Liu\& Han (2015, p. 149) referred to the academic words as, "lexical items that occur frequently and uniformly across a wide range of academic material". Each word family of the 570-word families has a head word and "all inflections and the most frequent, productive and regular prefixes and suffixes" (Coxhead, 2000, p. 218). "Words were selected based on occurring at least hundred times in an academic corpus of 3.5 million words of varied genres and in at least 15 of the 28 disciplines within the four broad subject groupings of the corpus: Arts, Commerce, Law and Science" (Coxhead, 2016, p. 221). 


\section{Enriching academic vocabulary of the undergraduates in technological study stream in Sri Lanka: A comparative exploration of the effectiveness of Virtual Blended and Face-to-Face modes}

Academic vocabulary consists of word families that occur frequently covering a wide range of academic subjects across many disciplines. Such learners are expected to go beyond the 2,000 high frequency words and learn the vocabulary of the academic word list. Initially Xue and Nation (1984) compiled the university word list containing 800-word families for learners at the tertiary level. Coxhead's (2000) work on academic vocabulary identified 570-word families with each word family having a head word. These words have been found through an analysis of a large corpus of university textbooks and academic writing and have been divided into ten sub lists based on their range and frequency in academic texts. Out of the ten sub lists, the first nine sub lists contain 60-word families whereas sub list ten contains 30 -word families. As indicated in the table 1, sub list one provides 3.6 percent coverage of the academic corpus, sub list two provides 1.8 percent coverage and so on. The first two sub lists together provide 5.4 coverage of the academic corpus. The table also illustrates the average frequency per $1,000,000$ words and the pages per repetition in the academic corpus.

Table 1: Coxhead's (2000) 570-word families with 10 sub lists on academic vocabulary

\begin{tabular}{|l|l|l|l|}
\hline AWL sub list & $\begin{array}{l}\text { Coverage of the } \\
\text { Academic Corpus } \\
(\%)\end{array}$ & $\begin{array}{l}\text { Pages per } \\
\text { repetition in the } \\
\text { Academic } \\
\text { Corpus }\end{array}$ & $\begin{array}{l}\text { Average } \\
\text { frequency per } \\
1,000,000 \text { words }\end{array}$ \\
\hline 1 (60 families) & $3.6 \%$ & 4 & 577 \\
2 (60 families) & $1.8 \%$ & 8 & 297 \\
3 (60 families) & $1.2 \%$ & 12 & 202 \\
4 (60 families) & $0.9 \%$ & 15 & 157 \\
5 (60 families) & $0.8 \%$ & 19 & 129 \\
6 (60 families) & $0.6 \%$ & 24 & 104 \\
7 (60 families) & $0.5 \%$ & 30 & 82 \\
8 (60 families) & $0.3 \%$ & 49 & 51 \\
9 (60 families) & $0.2 \%$ & 67 & 37 \\
10 (30 families) & $0.1 \%$ & 82 & 30 \\
\hline
\end{tabular}

For instance, words belonging to sub list one occurs 577 times per 1,000,000 running words and each of the 60 words in that sub list will be repeated every four pages of an academic text. As clearly seen from the table, the ten 
sub lists are organized in the order of frequency, from the sub list one belonging to the highest frequency to the tenth sub list belonging to the lowest frequency.

Receptive vocabulary refers to the words that are understood when they are read in a text or heard, and the meaning is retrieved. Productive vocabulary on the other hand, consists of words that can be recalled and used correctly to communicate in writing and speaking (Nation, 2001). In a revised and expanded version, the aspects of word knowledge are labeled as "either receptive or productive" (Nation, 2001, p. 27). Receptive vocabulary is commonly learnt before productive vocabulary and people know more words receptively than they do productively (Nation, 2001). Receptive activities have been found to be used more in teaching as these are easier to design and grade. On the other hand, productive activities are found to be time consuming and not so popular among the teachers. This study explored the level of receptive vocabulary knowledge by comparing the scores of an academic vocabulary test of two samples of participants who learnt in two modes and productive knowledge by analyzing the production of correct words in a vocabulary activity taking the same two groups of participants who learnt the same content in two different modes, VBM and F2F in the Faculty of Technology of the University of Colombo.

An overview of the methods of language teaching of the past indicates that vocabulary had not been given priority with grammar being given much emphasis. Even in the 1970's and early 1980's, with the introduction of the concept of communicative competence referred to by Hymes (1971), vocabulary had been given secondary position. Communicative approaches to foreign language teaching provided enough opportunities to interact with each other in the target language in natural settings. There is now a general agreement that vocabulary is at the heart of communicative competence (Coady and Huckin, 1997). It was mainly during the past decade due to computer- aided research, scholars were able to analyze lexical items in different corpora. During the same time, psycholinguistic studies gave them the insights concerning mental processes involved in vocabulary learning (Celce-Murcia, 2001). 
Enriching academic vocabulary of the undergraduates in technological study stream in Sri Lanka: A comparative exploration of the

effectiveness of Virtual Blended and Face-to-Face modes

\section{Approaches in teaching academic vocabulary}

More emphasis has been laid on the following four approaches as these approaches have had quite a significant impact on vocabulary teaching and learning. The four main approaches stated by Krashen (1989) are Contextual Acquisition Research, Strategy Instruction, Development plus Explicit Instruction and Classroom Activities. The second approach, the strategy instruction lays emphasis on teaching vocabulary learning strategies to learners so that they can use them effectively from context. Such instruction would be appropriate for advanced learners who need academic English in their career.

The development of extensive vocabulary knowledge for advanced literary purposes requires some direct instruction and strategy training (Huckin and Bloch, 1993; Parry and Williams, 1985). Through a study on Sudanese learners, Navathe \& Ahmed (1989) found that good learners not only used more vocabulary learning strategies but also relied more on different strategies than did poor learners. This study used an interview schedule to find out the most commonly used vocabulary teaching strategy in the Faculty of Technology randomly selecting lecturer sample of 21 from the total population of ESL teachers attached to the Department of English Language Teaching in the UOC.

\section{Strategy used to teach academic vocabulary in the present study}

The semantic mapping strategy was identified as the most commonly used vocabulary teaching strategy by the lecturers of ESL at the Faculty of Technology to develop students' academic vocabulary.

Graves (2008) stated that semantic mapping strategy is a powerful approach to teaching vocabulary because it helps students to think about word relationships. Studies have revealed that both semantic mapping and word mapping are effective in word learning. In semantic maps, there are graphic displays of word meanings that offer a visual representation of how words and concepts are related. It has been found to be an effective tool in the learning of content area concepts. Semantic mapping is effective as prereading and post-reading activities to assess learners' prior knowledge before reading and the knowledge after reading the text. 
A word map is similar to semantic map which is used mainly to promote vocabulary development. The head word will be at the center with branches giving additional information such as synonyms / dictionary definitions, antonym, example sentence, word family (other forms of the word). As the word map gives a visual representation of the word it helps to visualize different aspects of the word which in turn register in the minds of the learner. Furthermore, learners can work collaboratively in small groups which enable peer interaction and support. Each learner gets an opportunity to contribute his or her knowledge making it a rich and lively learning experience. Another interesting feature is that the word map could be made colorful by using different colors and preparing a poster and displaying it. It could also be done on a transparency and displayed using an overhead projector.

Allen (1983) suggests that vocabulary is best learned when it is encountered in the classroom situation when the learner perceives a need for it. The activities designed are categorized based on the level of instruction namely, the Beginning, Intermediate and Advanced level. Classroom based communicative activities such as pictures and games are suitable for Beginners, whereas small group tasks and simplified readings can be used for the Intermediate learners and dictionary work, morphological training and reading comprehension for the Advanced learners.

Nayar et al. (2020) addressed the need for higher student engagement in the classroom either online or face to face in producing better performance in higher education context. Their findings indicated the improved learning effectiveness of blended learning tools vis-à-vis traditional tools. The study recommended blended learning tools for educators aiming to transition from traditional learning to interactive learning to create experiential classrooms.

\section{The theoretical foundation}

Theories for this study were drawn from the Schema Theory of Richard Anderson (1977) and Sociocultural theory of Vygotsky (1978).

\section{Schema theory (1977)}

According to the Schema theory (1977), a meaningful learning occurs when the learner attempts to relate new information to what he or she already 


\section{Enriching academic vocabulary of the undergraduates in technological study stream in Sri Lanka: A comparative exploration of the effectiveness of Virtual Blended and Face-to-Face modes}

knows. This prior knowledge or prior experience is essential for comprehension of the printed word. Meaningful learning takes place when at least two things are properly organized: the reader's cognitive structure and the material to be learned. Cognitive structure may be defined as all of an individual's existing knowledge, "which according to Rumelhart and Ortony (1977) is incorporated into abstract conceptual frameworks or schema. Pearson and Spiro (1982, p. 46) describe schema as the little pictures or associations you create in your head when you read a word or sentence: "You can have a schema for an object (chair, boat, fan), an abstract idea or feeling (love, hat, hope), an action (dancing, swimming, buying), or an event (election, garage sale, concert)." The schema is explained as the "elaborate and meaningful mental network that organizes and stores mental representations of concepts' (Anderson, 1977). The schema theory plays a significant role in the ESL context especially in content area language teaching. The schemata of learners change as they gain more information on a given concept.

While exploring the recall of Native American folktales, Bartlett (1986) has noticed that many recalls were not accurate and involved the replacement of unfamiliar information with facts already known (Wagoner, 2017). In order to categorize this class of memory errors, Bartlett (1886-1969) has suggested that human beings apparently possess generic knowledge in the form of unconscious mental structures (schemata) and that these structures produce schematized errors in recall when they interact with incoming information. Thus, it is through schemata that old knowledge influences new information. So, basically, schemata (plural of schema) are psychological concepts that were proposed as a form of mental representation for selected chunks of complex knowledge, which are then stored in the long-term memory (Wagoner, 2017).

Schema theory emphasizes on the importance of generic knowledge that will help the formation of mental representations. In the educational process, the task of teachers would be to help students develop new schemata and establish connections between them -something that will eventually improve their memory. In this context, background information and prior knowledge are vitally important. The present study tried to prove the applicability of the Schema Theory in vocabulary learning for the students with limited prior 
knowledge in ESL comparing their vocabulary achievement with the outcome of the students with higher level of prior knowledge in ESL taking two samples of participants from the Faculty of Technology in the University of Colombo.

\section{Mediation concept of socio-cultural theory}

Mediation is regarded as the major concept of Vygotsky's theory of learning (Vygotsky, 1978). As he explains, mediation is the use of a tool to accomplish some action. Many of the tools are culturally and historically constructed objects and are made available to the child in social interaction. Some of the higher-level cultural tools are language, literacy, numeracy, rationality logic etc. Of all, language is the most powerful cultural artefact that human possesses to mediate their connection to the world, to each other and to themselves. This view shows that cognitive development is mediated through language and action during when lower order mental functions such as memory and involuntary actions are transformed into higher order mental thinking concepts such as logical and critical thinking, reasoning, high memory power intent attention, and critical analysis. This shows that cognitive development occurs as a result of mediation. For mediation to occur learning has to be initiated as a social activity in the process of interaction.

Vygotsky (1981) reveals that the language development of children takes place through interaction with others. In this way, children are connected and mediated to the world. Regulation is one form of mediation. Children develop the capacity to regulate their own activity through linguistic means by participating in both physical and mental activities in which their activities are initially subordinated or regulated by others. It is through this process that higher cognitive development emerges. Subsequently, the learner can do some activities with the help of a mediator and the learner's meta-cognition is under the control of others. This form of assistance is called scaffolding by peers, elders, siblings, parents, teachers, expert or adult. The concept of scaffolding is one form of mediation that has drawn attention in the socio-cultural perspective (Donato, 1994). 
Enriching academic vocabulary of the undergraduates in technological study stream in Sri Lanka: A comparative exploration of the effectiveness of Virtual Blended and Face-to-Face modes

As this researcher has chosen the perspective of learning as participation in VBM and F2F modes to study the effectiveness in academic vocabulary improvement in the process of teaching and learning ESL in a social context, it is important to see the nature of participation and how it contributes to the undergraduate learners.

\section{Research Methodology}

The research followed mixed method case study approach with both quantitative and qualitative techniques. Collection of vocabulary test scores and analysis of the data were carried on following quantitative methods while the data on commonly used vocabulary learning strategy was collected and analyzed for the qualitative part. Keeping all the factors such as time spent for practicing, word learning strategy used, academic vocabulary practicing activities constant, two variables, i.e. the mode of delivery and the improvement in academic vocabulary were considered in measuring the learning outcome of this study. The setting was the Faculty of Technology in the University of Colombo, which is situated in the city of Malambe, about $20 \mathrm{~km}$ away from the main University premises in Colombo 03. 


\section{The study design}

Figure 2: The study design (Author construction)

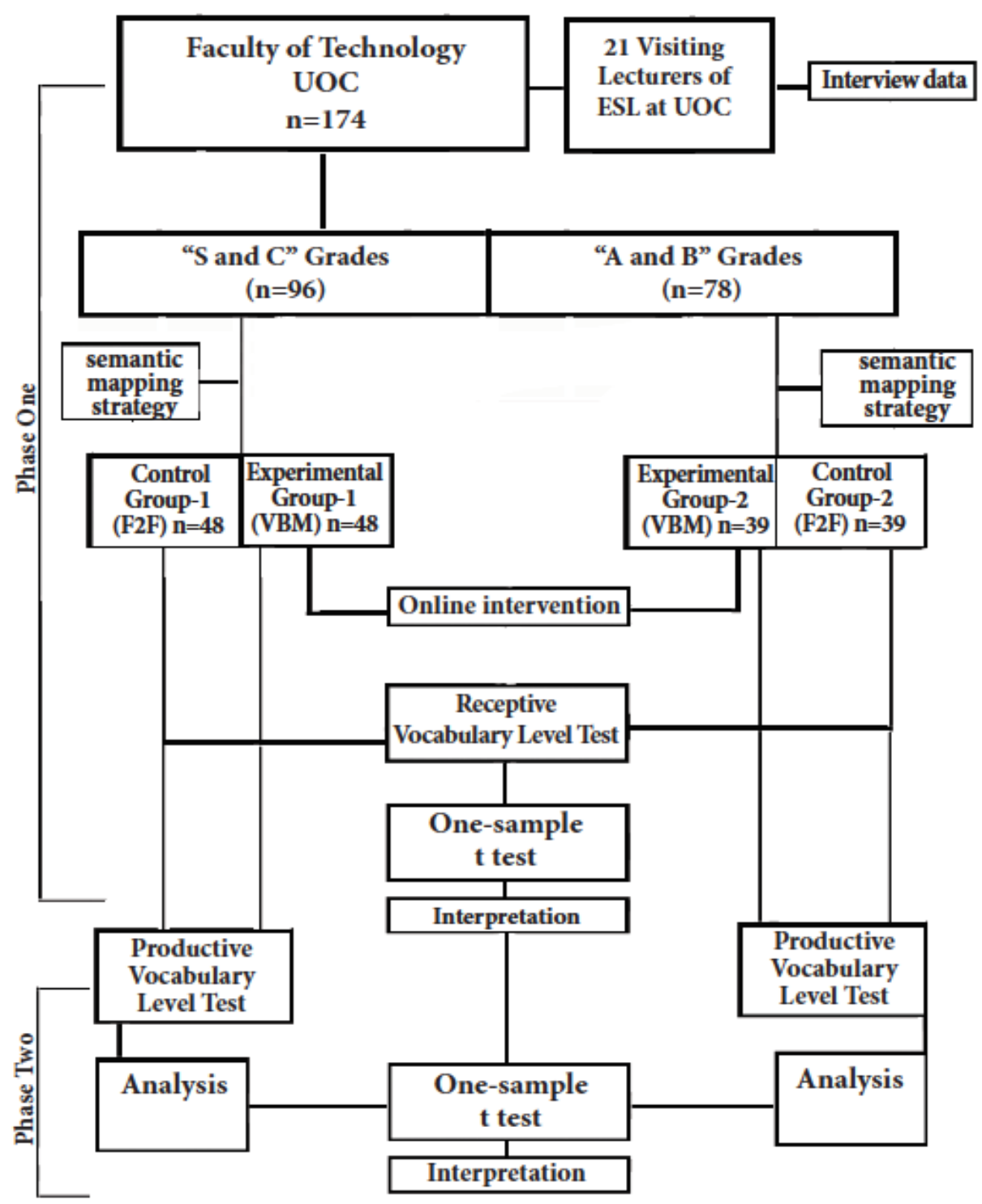




\section{Enriching academic vocabulary of the undergraduates in technological study stream in Sri Lanka: A comparative exploration of the \\ effectiveness of Virtual Blended and Face-to-Face modes}

The study employed 96 participants with limited prior knowledge and 78 participants with higher level of prior knowledge in English language, selected as two purposive samples from the total population of 174 in the 2018/2019 academic year in the Faculty of Technology. The first sample, the group with limited prior knowledge in ESL, consisted of all male and female ESL learners, aged 20 to 22 years who have secured ' $S$ ' or ' $C$ ' passes for General English at their G.C.E. Advanced Level Examination while the second sample, the group with higher level of prior knowledge in ESL, consisted of the students who have secured ' $A$ ' and ' $B$ ' passes. Participants in the two groups were then randomly assigned into VBM and F2F groups considering their registration numbers in the faculty.

\section{Research instruments}

Three research instruments were utilized for data collection for this study. The instruments were used as follows:

1). A questionnaire and an interview schedule for randomly selected 21 Visiting Lecturers of ESL at the Faculty of Technology were used to collect data on the demographic information, the most commonly used vocabulary teaching strategy, and the challenges faced by them in teaching vocabulary. The questionnaire was tested for content validity and pilot tested to assess its feasibility in the study.

2). A receptive vocabulary level test was executed for groups, the experimental and the control in both samples. The receptive vocabulary level questions were set based on the principles of Nation's vocabulary level test. The objective of this test was to assess and compare the participants' receptive vocabulary knowledge. In this test, a list of 36 words was given with definitions on the right side of the words to find the correct contextual meaning to the word. Such a test is objective and practical in terms of preparation and grading. Furthermore, it keeps the participants focused on the test till the end as it takes a short time, only one hour, to answer the questions. An assessment of the receptive knowledge was adequate at this stage as the researcher's objective was to enhance the knowledge of the chosen set of academic vocabulary through the implementation of the selected strategy and assess their receptive and productive knowledge at the end of the intervention. It was necessary to limit the number of words for the 
study to pay more attention to all aspects of each word within the given period. The target vocabulary for the intervention and the intended study was from a newly compiled list of 120 words from the Academic Word List of Coxhead (2000) as this would be a manageable number for the study duration, three months.

3). A Productive Vocabulary Level Test was executed for both groups in the two samples. The same words given both for the receptive and productive tests were taken from the 120-word list of academic vocabulary used for academic vocabulary practicing during the three months but the formats of the two tests were different. The productive test administered to test the participants' ability in applying their receptive vocabulary knowledge in a new context. Only the first three or four letters of the academic words were given, and the participants were expected to fill in the gaps of the sentences meaningfully. They were marked for accuracy using a rubric.

\section{Vocabulary intervention}

The semantic mapping strategy was identified as the most commonly used strategy by the lecturers who teach ESL to the respective participants. A semantic map is a visual representation of the word helping in vocabulary development which is used in the present study in the intervention. According to Graves (2008), mapping strategy is a powerful approach to teach vocabulary because it helps students to think about word relationships. This strategy helps to activate the learners' knowledge of the given words through brainstorming. The focus word will be the head word in the central position with branches as represented in Fig 6. The learners work in groups and draw a word map with the given word in the central position of the map. Each branch deals with an aspect of the word, such as synonyms or the meaning, antonyms, word family members and an example sentence. 
Enriching academic vocabulary of the undergraduates in technological study stream in Sri Lanka: A comparative exploration of the effectiveness of Virtual Blended and Face-to-Face modes

Figure 2: Visual representation of semantic word map strategy

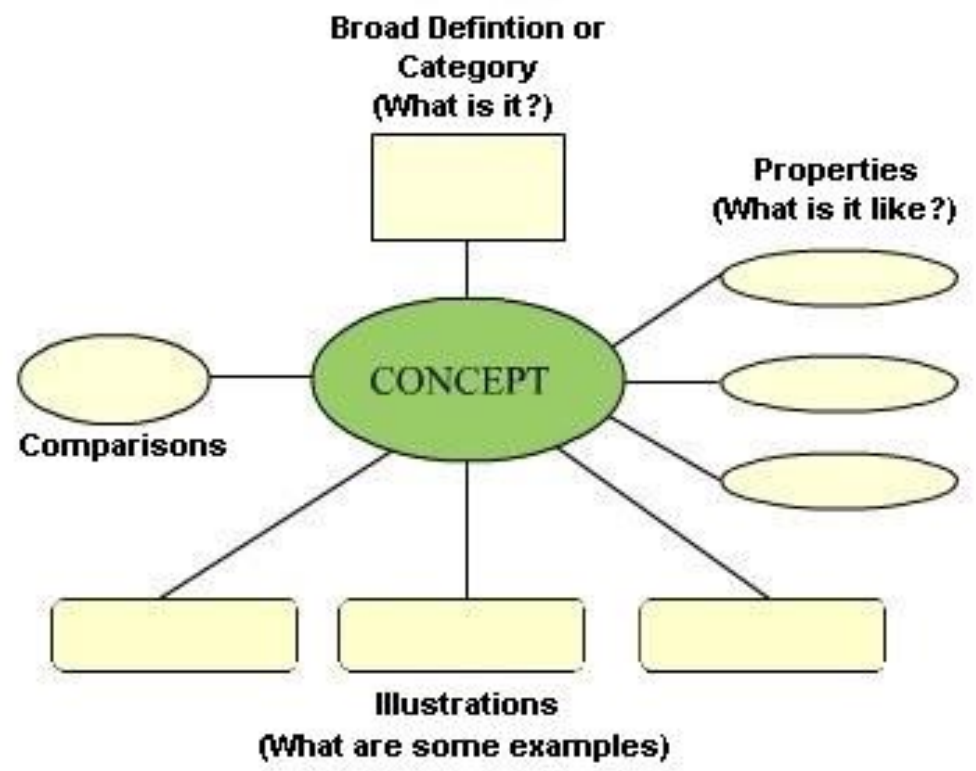

A special Learning Management System (LMS), equipped with the newest Web 2.0 feature, the BigBlueButton was created by the Faculty of Technology for the VBM group and it was accessible via the URL, http://lms.tech.cmb.ac.lk/course/index.php?categoryid=8. Two hours was allocated for the participants, for each activity on every Monday, Wednesday and Friday from 8.00 a.m. to 10.00 a.m. during the three months to practice vocabulary using the semantic mapping strategy. Four F2F sessions, in addition to the 32 online sessions were arranged for the VBM participants to meet their peers and the tutor in the physical classroom to receive instructions and feedback. The F2F group engaged in the same vocabulary learning activities with their tutor in the traditional classroom at the same time on the same 36 days using the same strategy. However, the practicing time given for both groups was set constant.

Participants were exposed to three to four new words in every session by including them into their vocabulary learning activities which were original for this study. Mean scores of the two groups of both samples were calculated and compared in assessing the level of outcome. 
A list of 120 words randomly chosen from the Academic Word List (Coxhead, 2000) of 570-word families was formulated for the purpose of this study. The receptive vocabulary test was carefully formulated and conducted to assess the participants' existing academic vocabulary knowledge by giving them 36 multiple choice questions. The participants of the VBM group were expected to select correct meanings of the academic vocabulary given online. The same test was administered to the F2F group in their class using the printed version of the same paper. Marks obtained were entered into the SPSS version 22.0 data sheet for analysis. The number of words used for the vocabulary intervention was limited to 120 words. Those 120 academic vocabularies were included into 36 vocabulary learning activities. Participants were exposed for activities for two hours on every Monday, Wednesday and Friday from 8.00 a.m. to 10.00 a.m. VBM participants practiced about 90 percent of their content (32/36 activities) online with a few, (4/32) lessons in F2F mode while the F2F Mode learners practiced 100 percent of the content in their traditional classrooms.

Vocabulary teaching strategies have been suggested as techniques which would facilitate vocabulary learning among second language learners (Clouston, 2008). Two modes of delivery, face-to-face and VBL were used to teach the same content to two groups of learners. Intervention was made to the experimental group using the newest feature on the WEB 2.0 Technology, The BigBlueButton which enabled real-time sharing of audio, video, and screen. In this regard, the students can use BigBlueButton as a generic web conferencing system for collaboration. BigBlueButton is designed mainly for collaboration and engagement with a focus on virtual tutoring, flipped classroom (recording content ahead of class) and full online classes. BigBlueButton uses a HTML5 client. As such, using BigBlueButton requires no downloads, no plugins, and no software installations. It loads within the browser with a single click. The HTML5 client provides a unified interface across desktop, laptop, chromebook, and mobile devices (iOS 11+ and Android 6.0+). 
Enriching academic vocabulary of the undergraduates in technological study stream in Sri Lanka: A comparative exploration of the

effectiveness of Virtual Blended and Face-to-Face modes

\section{Results and Discussion}

RQ 1- The first research question that was investigated through this research was to identify the most commonly used vocabulary teaching strategy by the lecturers teaching ESL at the Faculty of Technology in the University of Colombo. A randomly selected lecturer sample was administered a questionnaire and later they were interviewed on the vocabulary teaching strategy and demographic data.

Lecturer sample and data collected through the interview and the questionnaire are given in table 2 below. Each Visiting Lecturer (VL) has been assigned a code for identification.

Table 2: The lecturer sample

\begin{tabular}{|c|c|c|c|c|c|c|}
\hline & $\begin{array}{l}\text { Visiting } \\
\text { lecturer's } \\
\text { code }\end{array}$ & Gender & Age & $\begin{array}{c}\text { Experience } \\
\text { in teaching } \\
\text { ESL }\end{array}$ & $\begin{array}{l}\text { Professional } \\
\text { Qualification }\end{array}$ & $\begin{array}{c}\text { Commonly used } \\
\text { vocabulary } \\
\text { strategy }\end{array}$ \\
\hline 1 & VL1 & $\mathrm{F}$ & 35 & 10 & Graduate & Dictionaries \\
\hline 2 & VL2 & $\mathrm{F}$ & 43 & 9 & $\begin{array}{c}\text { Trained } \\
\text { Graduate }\end{array}$ & $\begin{array}{c}\text { Semantic mapping } \\
\text { strategy }\end{array}$ \\
\hline 3 & VL3 & $\mathrm{F}$ & 29 & 4 & Graduate & Word cards \\
\hline 4 & VL4 & M & 47 & 21 & Graduate & $\begin{array}{c}\text { Semantic mapping } \\
\text { strategy }\end{array}$ \\
\hline 5 & VL5 & $\mathrm{F}$ & 65 & 17 & Graduate & $\begin{array}{c}\text { Semantic mapping } \\
\text { strategy }\end{array}$ \\
\hline 6 & VL6 & $\mathrm{F}$ & 24 & 7 & $\begin{array}{c}\text { Trained } \\
\text { Graduate }\end{array}$ & $\begin{array}{c}\text { Negotiation } \\
\text { strategy }\end{array}$ \\
\hline 7 & VL7 & $\mathrm{F}$ & 28 & 7 & $\begin{array}{c}\text { Trained } \\
\text { Graduate }\end{array}$ & Word games \\
\hline 8 & VL8 & $\mathrm{F}$ & 43 & 7 & $\begin{array}{c}\text { Trained } \\
\text { Graduate }\end{array}$ & $\begin{array}{c}\text { Semantic mapping } \\
\text { strategy }\end{array}$ \\
\hline 9 & VL9 & $\mathrm{F}$ & 41 & 9 & $\begin{array}{c}\text { Trained } \\
\text { Graduate }\end{array}$ & $\begin{array}{c}\text { Semantic mapping } \\
\text { strategy }\end{array}$ \\
\hline 10 & VL10 & $\mathrm{F}$ & 52 & 25 & $\begin{array}{l}\text { Trained } \\
\text { Graduate }\end{array}$ & $\begin{array}{c}\text { Negotiation } \\
\text { strategy }\end{array}$ \\
\hline 11 & VL11 & $\mathrm{F}$ & 56 & 11 & $\begin{array}{l}\text { Trained } \\
\text { Graduate }\end{array}$ & $\begin{array}{c}\text { Semantic mapping } \\
\text { strategy }\end{array}$ \\
\hline
\end{tabular}




\begin{tabular}{|c|c|c|c|c|c|c|}
\hline 12 & VL12 & F & 50 & 19 & $\begin{array}{c}\text { Trained } \\
\text { Graduate }\end{array}$ & $\begin{array}{c}\text { Semantic mapping } \\
\text { strategy }\end{array}$ \\
\hline 13 & VL13 & F & 48 & 20 & $\begin{array}{c}\text { Trained } \\
\text { Graduate }\end{array}$ & $\begin{array}{c}\text { No specific } \\
\text { strategy is used }\end{array}$ \\
\hline 14 & VL14 & F & 30 & 6 & $\begin{array}{c}\text { Trained } \\
\text { Graduate }\end{array}$ & $\begin{array}{c}\text { Semantic mapping } \\
\text { strategy }\end{array}$ \\
\hline 15 & VL15 & F & 48 & 20 & $\begin{array}{c}\text { Trained } \\
\text { Graduate }\end{array}$ & $\begin{array}{c}\text { Semantic mapping } \\
\text { strategy }\end{array}$ \\
\hline 16 & VL16 & F & 38 & 11 & Graduate & $\begin{array}{c}\text { Semantic mapping } \\
\text { strategy }\end{array}$ \\
\hline 17 & VL17 & M & 47 & 16 & Graduate & $\begin{array}{c}\text { Semantic mapping } \\
\text { strategy }\end{array}$ \\
\hline 18 & VL18 & F & 54 & 24 & Graduate & $\begin{array}{c}\text { Semantic mapping } \\
\text { strategy }\end{array}$ \\
\hline 19 & VL19 & F & 32 & 10 & Graduate & $\begin{array}{c}\text { Semantic mapping } \\
\text { strategy }\end{array}$ \\
\hline 20 & VL20 & F & 42 & 18 & Graduate & $\begin{array}{c}\text { Semantic mapping } \\
\text { strategy }\end{array}$ \\
\hline 21 & VL21 & F & 26 & 2 & Graduate & $\begin{array}{c}\text { Semantic mapping } \\
\text { strategy }\end{array}$ \\
\hline
\end{tabular}

\section{Source: Author construction}

The results of the lecture interview data and questionnaire data analysis showed that 71 percent $(15 / 21)$ of the lecturers of ESL teaching in the Faculty of Technology used the Semantic Mapping Strategy to teach academic vocabulary. After identifying the most commonly used strategy, students were instructed on using it for academic vocabulary practicing of this study and it was the only strategy used for the intervention of this study.

RQ 2- The second research question that was investigated through this research was to examine how far the two modes of delivery, VBM and F2F were effective in developing receptive and productive academic vocabulary of the participants with limited prior knowledge in ESL.

The answer scripts of both groups in both samples of participants were marked for the correct and wrong answers using the rubric and the answers were entered into the SPSS 22.0 version. Each correct answer was taken as one score and therefore the total score was calculated out of 100 . The mean value was calculated for each group using the version 22.0 of the SPSS software. 
Enriching academic vocabulary of the undergraduates in technological study stream in Sri Lanka: A comparative exploration of the

effectiveness of Virtual Blended and Face-to-Face modes

Table 3: Receptive vocabulary knowledge improvement of the sample with limited ESL knowledge in VBM and F2F.

\begin{tabular}{l|c|c|c|c}
\hline & N & Mean & $\begin{array}{l}\text { Std. } \\
\text { Deviation }\end{array}$ & $\begin{array}{l}\text { Std. Error } \\
\text { Mean }\end{array}$ \\
\hline VBMRecepLimited & 48 & 67.19 & 8.134 & 1.174 \\
\hline F2FRecepLimited & 48 & 56.60 & 10.993 & 1.587 \\
\hline
\end{tabular}

Significance level $\mathrm{p}<.005$

Table 3 shows that the VBM group participants with limited prior knowledge in ESL have scored 67.19 percent mean mark for the receptive vocabulary test while F2F participants in the same sample scored less (56.60 percent).

Table 4: Productive vocabulary knowledge improvement in the sample with limited Prior knowledge in ESL in VBM and F2F

\begin{tabular}{l|c|c|c|c}
\hline & $\mathrm{N}$ & Mean & $\begin{array}{c}\text { Std. } \\
\text { Deviation }\end{array}$ & Std. Error Mean \\
\hline VBMProdLimited & 48 & 44.77 & 6.540 & .944 \\
\hline F2FProdLimited & 48 & 48.38 & 8.955 & 1.293 \\
\hline
\end{tabular}

Significance level $p<.005$

Table 4 reveals that the VBM group participants with limited prior knowledge in ESL have scored only 44.77 percent mean mark for the productive vocabulary test while F2F participants in the same sample scored a little more ( 48.38 percent) but both scores remain low $(<50 \%)$ compared to their receptive test scores showing that the mode of learning does not make a significant difference in their productive vocabulary improvement.

RQ 3- The third research question that was investigated through this research was to examine how far the two modes of delivery, VBM and F2F were effective in developing receptive and productive academic vocabulary of the participants with higher level of prior knowledge in ESL. 
Table 5: Receptive vocabulary knowledge improvement in the sample with higher ESL knowledge in VBM and F2F.

\begin{tabular}{l|c|c|c|c}
\hline & $\mathrm{N}$ & Mean & $\begin{array}{c}\text { Std. } \\
\text { Deviation }\end{array}$ & $\begin{array}{c}\text { Std. Error } \\
\text { Mean }\end{array}$ \\
\hline VBMRecepHigher & 39 & 77.03 & 7.520 & 1.204 \\
\hline F2FRecepHigher & 39 & 62.51 & 8.632 & 1.382 \\
\hline
\end{tabular}

Significance level $p<.005$

Table 5 shows that the VBM group participants with higher knowledge in ESL have scored a high (77.03 percent) mean mark for the receptive vocabulary test while F2F participants in the same sample scored less (62.51 percent) but both scores are significantly higher than those in limited prior knowledge groups.

Table 6: Productive vocabulary knowledge improvement in the sample with higher knowledge in ESL in VBM and F2F

\begin{tabular}{l|c|c|c|c}
\hline & $\mathrm{N}$ & Mean & $\begin{array}{c}\text { Std. } \\
\text { Deviation }\end{array}$ & Std. Error Mean \\
\hline VBMProdHigher & 39 & 76.21 & 3.962 & .634 \\
\hline F2FProdHigher & 39 & 76.03 & 4.777 & .765 \\
\hline
\end{tabular}

Significance level $\mathrm{p}<.005$

Table 6 shows that the VBM group participants with higher knowledge in ESL have scored 76.21 percent mean mark for the productive vocabulary test while F2F participants too in the sample scored nearly the same improvement (76.03 percent) but both mean scores remain high (>75\%).

An analysis of the receptive vocabulary test results indicated a significant improvement in the receptive vocabulary knowledge improvement of the two experimental groups who had undergone vocabulary intervention with the help of the VBM online compared to their counterparts who practiced the same vocabulary learning materials in the traditional F2F mode (Tables 3 and 5).

Table 6 results show that the mode of delivery does not influence the productive vocabulary learning of the participants with higher level of prior 


\section{Enriching academic vocabulary of the undergraduates in technological study stream in Sri Lanka: A comparative exploration of the effectiveness of Virtual Blended and Face-to-Face modes}

knowledge in ESL as both groups, VBM and F2F, have scored equally higher scores for the productive vocabulary test in that sample. This shows that the ability to apply the learned concepts in a new context depends on the prior knowledge of the learner than on the mode of delivery being utilized.

\section{Conclusion}

The study adopted both qualitative and quantitative research methods to find answers to the focal research questions. The research procedure was scientifically administered involving purposive sampling, intervention phase and two posttests. The statistical comparison was also well based considering two samples as the participants with limited prior knowledge in ESL and higher level of prior knowledge in ESL. The results showed an improvement in the outcome of the receptive vocabulary knowledge of the participants in the VBM groups in both samples after the intervention. However, the participants with limited prior knowledge scored less in productive test compared to their receptive test were showing difficulty in using new words in new contexts proving the Schema Theory (Anderson, 1977) while the participants with higher ESL knowledge performed well in both receptive and productive tests. The study emphasizes the need for more involvement, strategically or pedagogically in enriching the vocabulary of the students in the Faculty of Technology with limited prior knowledge in ESL regardless of the mode of delivery being utilized.

The undergraduates taken for this research were from the Faculty of technology in the University of Colombo in which they must cope with English medium instruction while acquiring the new concepts relevant to their subjects. They need to be exposed to many academic words in their first year of study for them to overcome the challenge of achieving set learning outcomes. In order to enhance the learners' academic vocabulary, it was necessary to introduce and apply at least one strategy that would guide them towards autonomous learning of new words. The researcher identified the semantic mapping strategy by analyzing the data collected at the lecturer interviews which was also adapted from an earlier research by Graves (2006) on vocabulary instruction. As the aim of the researcher was to enhance both the receptive and productive knowledge, the strategy should target towards that end. 
The results of the receptive vocabulary level test for the 36 words indicated a significant improvement of the receptive knowledge in academic vocabulary of the participants who followed the vocabulary learning activities in VBM compared to those in F2F groups. This result was observed in both samples of participants, i.e. of the participants with limited prior knowledge in ESL and of the participants with higher level of prior knowledge in ESL. A comparison of the mean values of the test scores of both those experimental groups showed a significant improvement in the receptive vocabulary knowledge but it was not noticeable at the productive level test which tested the participants' ability of applying the receptive knowledge in new contexts. In comparison, there is an increase in the scores of the experimental group compared to those in the controlled groups. This provides evidence to support the Vygotsky's Socio-cultural Theory $(1978,1981)$ that has shown more collaborative environments -that involved both online and F2F environments in this study- support better learning.

Productive vocabulary test was conducted to test the participants' ability of using the receptive knowledge in a new context. A statistical analysis of the scores of the test indicated that the productive knowledge of the participants with limited prior knowledge in ESL was not sufficiently improved in any of the modes utilized in teaching. This supports the Richard Anderson's (1977) Schema Theory which has shown less capability of applying the existing knowledge in new situations when the learner's prior knowledge in the subject is limited. Proving the theory further, the participants with higher level of prior knowledge, in the sample two, have shown higher performance in the productive vocabulary test regardless of the mode of delivery being utilized as a teaching pedagogy.

Research on blended learning and English teaching and learning has increased as researchers have looked for ways to use this educational model in teaching English as a second/foreign language (ESL/EFL). Blended learning has been the focus of many research studies (Adas \& Bakir, 2013; Akbarov, Gonen, and Aydogan, 2018; Alias \& Pandian, 2012; Ghazizadeh and Fatemipour, 2017; Grgurovic, 2011; Liu, 2013; Manan, Alias, \& Pandian, 2012; Shih, 2010; Yoon \& Lee, 2010; Zhang \& Zhu, 2018) that investigated the use and the effectiveness of blended learning in the ESL/EFL context. Several academic and social benefits of using this 


\section{Enriching academic vocabulary of the undergraduates in technological study stream in Sri Lanka: A comparative exploration of the \\ effectiveness of Virtual Blended and Face-to-Face modes}

teaching approach have been identified. For instance, Marsh (2012) mentioned that the use of blended learning could provide many benefits to language learners over traditional teaching approaches. Some of these benefits include developing language learners' autonomy, providing more individualized language support, promoting collaborative learning, increasing students' interaction and engagement, providing opportunities to practice the language beyond the class settings, and improving the language skills of language learners.

All the participants included in this study were from the Faculty of Technology in the University of Colombo. Students in the Faculty of Technology are equipped with a better knowledge in computer applications and online learning tools compared to the students in the Faculties of Humanities and Management as their subjects are more related to the field of new technological advancement. However, the findings of this study show that even the learners in the Faculty of Technology do not benefit much in using online tools or technological advancements when learning English as a Second Language. Therefore, it is questionable whether the use of technology as was applied in this study and moving onto teaching ESL fully online or in virtual blended modes to the students in the Faculties of Arts and Management would bring about expected outcomes.

This study would be beneficial to the ESL learners and the teachers in the technological study field. It increases their awareness of academic vocabulary and motivates them towards using these words in their studies in an EAP context. This study explored which mode of delivery, either F2F or VBM, is more effective in developing receptive vocabulary amongst the tertiary level learners in the field of Technology. It also explored the effect of the receptive vocabulary improvement on the productive vocabulary improvement when the participants are with a limited prior knowledge and a higher level of prior knowledge in ESL. Future studies could pivot on different aspects of ESL learning and expand the research scopes related to vocabulary learning in different settings. More ESL components such as reading, writing, listening and speaking might also be examined in the two modes, VBM and F2F modes of delivery. 


\section{Acknowledgments}

The author wishes to thank all the people who helped to carry on this study at the Faculty of Technology in the University of Colombo during the academic year 2018/2019.

\section{References}

Abeysekera, L, Dawson, P (2015) Motivation and cognitive load in the flipped classroom: Definition, rationale and a call for research. Higher Education Research and Development 34(1): 1-14.

Adas, D., \& Bakir, A. (2013). Writing difficulties and new solutions: Blended learning as an approach to improve writing abilities. International Journal of Humanities and Social Science, 3(9), 254-266.

Akbarov, A., Gonen, K., and Aydogan, H. (2018). Students' attitudes toward blended learning in EFL context. Acta Didactica Napocensia, 11(1), 61-68. doi:10.24193/adn.11.1.5.

Alharbi, A. M. (2015). Building vocabulary for language learning: Approach for ESL learners to study new vocabulary. Journal of International Students, 5(4), 501- 511.

Allen, V. F. (1983). Techniques in Teaching Vocabulary. Oxford University Press, 200 Madison Ave., New York.

Allwright, D. (1990). Autonomy in language pedagogy. CRILE Working Paper, 6.

Anderson, R. C. (1977). Schema-directed processes in language comprehension. In Cognitive psychology and instruction (pp. 67-82). Springer, Boston, MA.

Celce-Murcia, M. (2001). Language teaching approaches: An overview. Teaching English as a Second or Foreign Language, 2, 3-10.

Celce-Murcia, M., \& McIntosh, L. (1991). Teaching English as a second or foreign language.

Chamot, A. U. (2007). Accelerating academic achievement of English language learners. In International handbook of English language teaching (pp. 317-331). Springer, Boston, MA.

Coady, J. (1997). L2 vocabulary acquisition. Second language vocabulary acquisition, 273-290. 
Enriching academic vocabulary of the undergraduates in technological study stream in Sri Lanka: A comparative exploration of the effectiveness of Virtual Blended and Face-to-Face modes

Coady, J., \& Huckin, T. (1997). Second language vocabulary acquisition: A rationale for pedagogy. Cambridge University Press.

Coxhead, A. (2016). Reflecting on Coxhead (2000)," A New Academic Word List". Tesol Quarterly, 50(1), 181-185.

Coxhead, A., \& Nation, P. (2001). The specialized vocabulary of English for academic purposes. Research perspectives on English for academic purposes , 252-267.

Cummins, J. (2002). Bilingualism and second language learning. Annual Review of Applied Linguistics, 13, 50-70.

Dima Ali Hijazi, Amal Shehadeh Al Natour. (2020) The Effect of Using Blended Learning Method on Students' Achievement in English and Their Motivation Towards Learning It. International Journal of Virtual and Personal Learning Environments 10:2, pages 83-96.

Eldridge, J. (2008). No, There Isn't an' Academic Vocabulary, 'but...” A Reader Responds to K. Hyland and P. Tse's "Is There an 'Academic Vocabulary'? TESOL quarterly, 42(1), 109-113.

Ellis, R., Tanaka, Y., \& Yamazaki, A. (1994). Classroom interaction, comprehension, and the acquisition of L2 word meanings. Language learning, 44(3), 449-491.

Graves, K. (2008). The language curriculum: A social contextual perspective. Language teaching, 41(2), 147-181.

Huckin, T., \& Bloch, J. (1993). Strategies for inferring word meaning from context: A cognitive model, Second language reading and vocabulary learning (pp. 153-178). Hymes, D. Competence and performance in linguistic theory. In R. Huxley \& E. Ingram (Eds.), Language acquisition: Models and methods. New York: Academic Press, 1971.

Krashen, S. (1989). We acquire vocabulary and spelling by reading: Additional evidence for the input hypothesis. The modern language journal, 73(4), 440-464. 
Laufer, B. (2011). The contribution of dictionary use to the production and retention of collocations in a second language. International Journal of Lexicography, 24(1), 29- 49.

Lessard-Clouston, M. (2008). Strategies and success in technical vocabulary learning: Students' approaches in one academic context. Indian Journal of Applied Linguistics, 34(1/2), 31 .

Little, D. (1991). Learner Autonomy 1: definitions, issues and problems. Dublin: Authentik.

Liu, J., \& Han, L. (2015). A corpus-based environmental academic word list building and its validity test. English for Specific Purposes, 39, 1-11.

Marzano, R. J., \& Pickering, D. J. (2005). Building academic vocabulary: Teacher's manual. Association for Supervision and Curriculum Development. 1703 North Beauregard Street, Alexandria, VA 223111714.

Nation, I.S.P. (2001). Learning Vocabulary in another Language. Cambridge: Cambridge University Press.

Nation, P., \& Newton, J. (1997). 19 teaching vocabulary. Second language vocabulary acquisition: a rationale for pedagogy, 238.

Nation, P., \& Waring, R. (1997). Vocabulary size, text coverage and word lists. Vocabulary: $\quad$ Description, acquisition and pedagogy, 14, 6-19.

Nation, P., Waring, R., Schmitt, N., \& McCarthy, M. (1997). Vocabulary: description, acquisition and pedagogy. Japan: Notre Dame Seishin University, 6.

National Governors Association. (2010). Common core state standards. Washington, DC.

Navathe, S. B., \& Ahmed, R. (1989). A temporal relational model and a query language. Information Sciences, 49(1-3), 147-175.

Nayar, B. and Koul, S. (2020), Blended learning in higher education: a transition to experiential classrooms, International Journal of Educational Management, Vol. ahead-of-print No. ahead-of-print. https://doi. org /10.1108/IJEM-08-2019-0295 
Enriching academic vocabulary of the undergraduates in technological study stream in Sri Lanka: A comparative exploration of the effectiveness of Virtual Blended and Face-to-Face modes

Nayar, B. and Koul, S. (2020), Blended learning in higher education: a transition to experiential classrooms, International Journal of Educational Management, Vol. ahead-of-print No. ahead-of-print. https://doi.org/ 10. $\underline{\text { 1108/IJEM-08-2019-0295 }}$

Newton, J. (1995). Task-based interaction and incidental vocabulary learning: A case study. Second Language Research, 11(2), 159-176.

O'malley, J. M., O'Malley, M. J., Chamot, A. U., \& O'Malley, J. M. (1990). Learning strategies in second language acquisition. Cambridge university press.

Oxford, R. (1990). Language learning strategies. New York, 3.

Paribakht, T. S., \& Wesche, M. B. (1993). Reading comprehension and second language development in a comprehension-based ESL program. TESL Canada journal, 09-29.

Pearson, P. D., \& Spiro, R. (1982). The new buzz word in reading is schema. Instructor, 91(9), 46-48.

Reed, N. C. (2004). The Specter of Wall Street:" Bartleby, the Scrivener" and the Language $\quad$ of Commodities. American Literature, 76(2), 247-273.

Richards, J.C. \& Renandya, W.A. (2003). Methodology in Language Teaching: An Anthology of Current Practice. Cambridge: Cambridge University Press.

Rumelhart, D. (1984). E., Ortony A., 1977. The representation of knowledge in memory. Schooling and the acquisition of knowledge, 99-135.

Sareen, S. K. (2009). Undergraduate English language teaching in Sri Lanka: policy, practice and perspectives.

Schmitt, N \& McCarthy, M., (eds.) (2005).Vocabulary: Description, Acquisition and Pedagogy. Cambridge: Cambridge University Press. 
Schmitt, N. (1995). A fresh approach to vocabulary using, a word knowledge framework. RELC Journal, 26, 86-94. Schmitt, N. (2000). Vocabulary in Language Teaching. Cambridge: Cambridge University Press.

Schmitt, N. (2002b). Vocabulary in Language Teaching. Cambridge: Cambridge University Press.

Schmitt, N. (ed.) (2002a).An Introduction to Applied Linguistics. New York: Oxford University Press.

Schmitt, N., \& Redwood, S. (2011). Learner knowledge of phrasal verbs: A corpus-informed study. A taste for corpora: In honour of Sylviane Granger, 173-209.

Stahl, S. A., \& Nagy, W. E. (2006). The literacy teaching series. Teaching word meanings.Mahwah, NJ, US: Lawrence Erlbaum Associates Publishers.

Wagoner, B. (2017). The constructive mind: Bartlett's psychology in reconstruction. Cambridge University Press.

Washburn, E. K., Joshi, R. M., \& Binks-Cantrell, E. S. (2011). Teacher knowledge of basic language concepts and dyslexia. Dyslexia, 17(2), 165183.

West, M. P. (Ed.). (1953). A general service list of English words: with semantic frequencies and a supplementary wordlist for the writing of popular science and technology. Longmans, Green.

Worthington, D., \& Nation, I. S. P. (1996). Using texts to sequence the introduction of new vocabulary in an EAP course. RELC Journal, 27.

Xue, G., \& Nation, I. S. P. (1984). A university word list. Language learning and communication, 3(2), 215-229. 